\title{
Divergent Histopathology in RCC: A Rare Entity
}

\author{
Manjeet Kumar*, Ritambra Nada and Santosh Kumar \\ Department of Urology, Indira Gandhi Medical College, India
}

*Corresponding author: Manjeet Kumar, Department of Urology, Indira Gandhi Medical College, India

\begin{tabular}{|c|c|}
\hline ARTICLE INFO & ABSTRACT \\
\hline Received: 慧 April 30, 2019 & Citation: Manjeet Kumar, Ritambra Nada, Santosh Kumar. Divergent Histopathology in \\
\hline Published: 蔧 May 08, 2019 & RCC: A Rare Entity. Biomed J Sci \& Tech Res 17(5)-2019. BJSTR. MS.ID.003061. \\
\hline
\end{tabular}

\section{Mini Review}

Sarcomatoid carcinoma is a phenotype of renal cell carcinoma which is independent of the histologic subtype and signals a poor prognosis. Farrow et al first described sarcomatoid carcinoma in renal cell carcinoma. Sarcomatoid differentiation is present in about 5\% of RCCs and diagnosis is established by presence of epithelial component which must be identified morphologically, ultrastructurally, or immunohistochemically [1]. It is high-grade de

differentiation of renal cell carcinoma. Generally, the sarcomatoid components show features of malignant fibrous histiocytoma or fibrosarcoma. Heterologous differentiation such as chondrosarcoma-, osteosarcoma-, and rhabdomyosarcoma-like differentiation is rare [2,3] Sarcomatoid RCC is not considered a distinct subtype of RCC by 2004 WHO classification; rather, it is thought to represent a high-grade and poorly differentiated component.

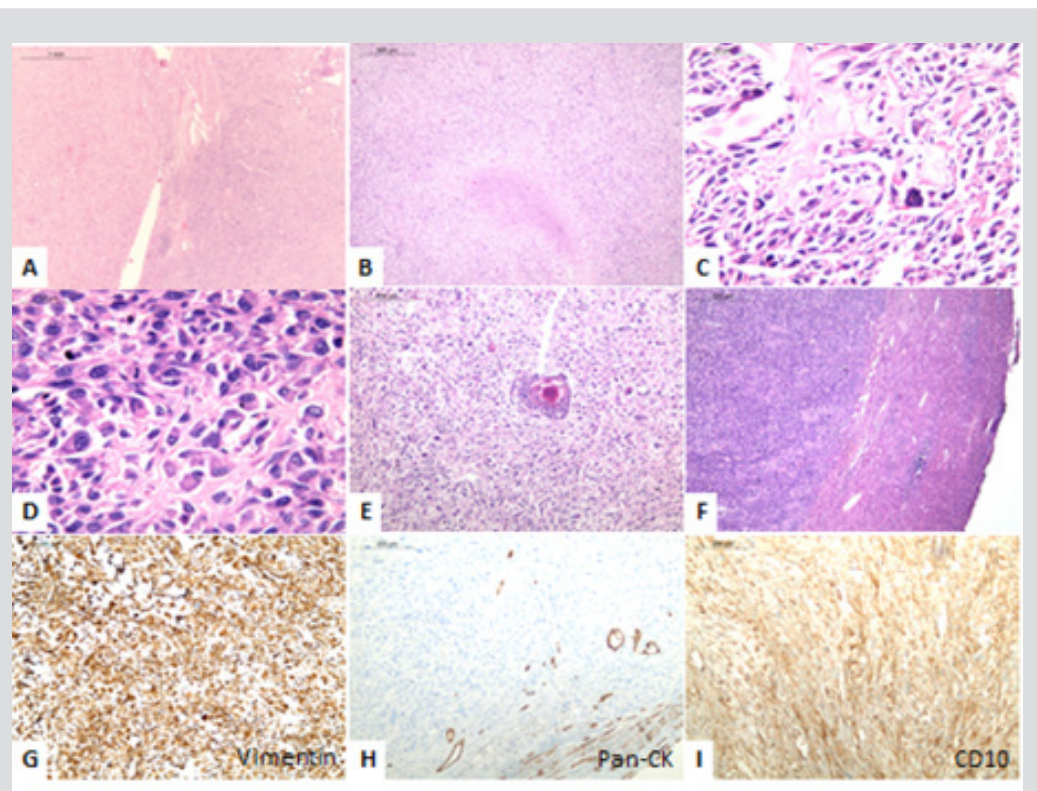

Figure 1: Renal cell carcinoma with divergent differentiation. A) The photograph shows partially demarcated highly cellular renal tumour with adjoining spared renal parenchyma. B) The tumor predominantly displays sarcomatoid areas in fascicles with foci of necrosis. C) Most of the areas exhibit osteosarcoma-like differentiation with osteoid producing tumour cells. D) At places, rhabdoid morphology in tumour cells is also evident. E) Small foci of squamoid differentiation is seen. F) Tumour is seen reaching the liver parenchyma indicating capsular breach and extension beyond Gerota's fascia. G) Vimentin immunostain performed shows diffuse strong cytoplasmic positivity in tumour cells. H) Pan-cytokeratin immunostain is negative in tumour areas; however the periphery shows entrapped normal tubular component of renal parenchyma. I) CD10 immunostain is diffusely positive (cytoplasmic) in tumour cells. 
Sarcomatoid components usually appear as bulging, lobulated areas with white to gray, firm and fibrous cut surface within a tumor. Histologically, the sarcomatoid component ranges from malignant spindle cells to those resembling leiomyosarcoma, fibrosarcoma, angiosarcoma, rhabdomyosarcoma, and other sarcomas [2]. Rhabdoid differentiation can be identified in approximately $5 \%$ of RCCs with tumor cells having large eccentric nuclei, macronucleoli and prominent acidophilic globular cytoplasm. It is also significantly associated with an increased likelihood of distant metastasis and cancer-specifc death [3]. Our patient presented with right renal mass (T2bN1M0). Right radical nephrectomy was done. Histopathology of renal mass was suggestive of divergent

\section{ISSN: 2574-1241}

DOI: 10.26717/BJSTR.2019.17.003061

Manjeet Kumar. Biomed J Sci \& Tech Res

This work is licensed under Creative Commons Attribution 4.0 License

Submission Link: https://biomedres.us/submit-manuscript.php histopathology in Renal cell carcinoma. The detailed histopathology is described in Figure 1.

\section{References}

1. de Peralta-Venturina M, Moch H, Amin M, Tamboli P, Hailemariam S, et al. (2001) Sarcomatoid differentiation in renal cell carcinoma: A study of 101 cases. Am J Surg Pathol 25: 275-284.

2. Cheville JC, Lohse CM, Zincke H, Weaver AL, Leibovich BC, et al. (2004) Sarcomatoid renal cell carcinoma: An examination of underlying histologic subtype and an analysis of associations with patient outcome. Am J Surg Pathol 28: 435-441.

3. Gökden N, Nappi O, Swanson PE, Pfeifer JD, Vollmer RT, et al. (2000) Renal cell carcinoma with rhabdoid features. Am J Surg Pathol 24: 13291338.

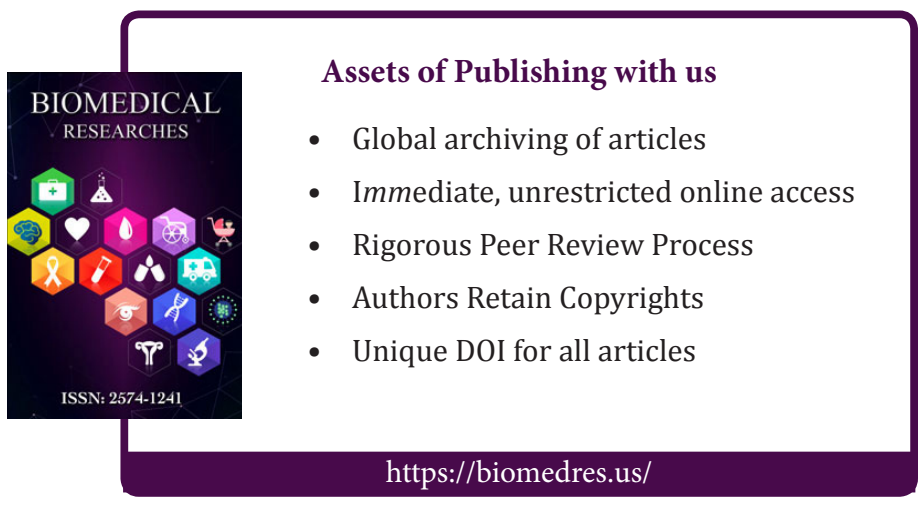

